\title{
Life, the movie
}

\section{Fifty years after revealing the structure of DNA, James Watson looks back.}

\section{DNA: The Secret of Life}

by James D. Watson with Andrew Berry

Alfred A. Knopf: 2003. 416 pp. \$29.95.

William Heinemann: 2003. $£ 20$

\section{Maxine Singer}

In an age when celebrities matter, biology has produced two: the DNA double helix and James D. Watson. Both emerged 50 years ago, and celebrations of that anniversary, including this book, abound. Lest he be forgotten, the book is dedicated to Francis Crick, who, since discovering with Watson the structure of DNA, has eschewed iconic status while contributing important, insightful ideas to biology. In the fashion of movie stars and sports heroes, this book was written 'with' Andrew Berry, who was initially recruited to work on the associated five-part television series, already shown on Channel 4 in Britain and to be aired on the Public Broadcasting System in the United States in April. According to the authors' note, three additional people wrote substantial parts of the book. Perhaps that's why, despite the firstperson-singular pretence, I missed Watson's provocative and sometimes maddeningly idiosyncratic style.

All of the people and stories associated with the landmark discoveries in genetics are here, from Gregor Mendel to the latest failures of gene therapy. They include the story of Thomas Hunt Morgan and the chromosomal theory of heredity; George Beadle and the 'one gene-one enzyme' concept; Oswald Avery, Alfred Hershey and Martha Chase and the identification of DNA as the hereditary molecule; François Jacob and Jacques Monod and the regulation of gene expression; Marshall Nirenberg and Gobind Khorana and the genetic code; and Mary-Claire King and the identification of genes associated with breast cancer. Research is realistically portrayed as a human endeavour that is subject to the quirks of personalities.

Unfortunately, however, for all its marvellous and comprehensive sweep, this book is flawed by some distressing errors. For example, in The Path to the Double Helix, Robert Olby carefully documents that Crick proposed the antiparallel configuration of the two DNA chains before Watson got the base pairing correct, but here the two insights are reversed. The technique used to produce Affymetrix DNA chips is described as "precise micropipetting" rather than an inspired marriage of computerized photolithography and photochemistry. The history of the development of recombinant-DNA concepts is garbled: combinations of eukaryote and bacterial plasmid or bacteriophage DNA were made by several investigators at Stanford University in California, albeit by inconvenient methods, well before Stanley Cohen and Herbert Boyer devised a convenient way to produce recombinant DNA molecules. The modern form of the method for importing plasmids into Escherichia coli bacteria was described by Mandel and Higa in 1970, rather than by Cohen in 1971. In addition, the definition of 'autosomal' is inexplicably confused with that of 'dominant', and the definition of 'cloning' is incomplete.

Genetics has been a lightning rod for public concern for almost a century. Watson and his co-authors recount the issues from the destructive influence of eugenics, through Trofim Lysenko and the controversies over genetically modified plants, to the forensic analysis of DNA. A chapter called "Defying Disease" superbly parses the complex questions surrounding genetic testing and diagnosis in a manner that is informative for biomedical scientists and patients alike. The authors' note acknowledges Jan Witkowski for "pulling together" this and two other chapters; if that means he wrote them, he has provided some of the book's most engaging narratives.

Watson is rightfully proud of his decision, as the first director of the Human Genome Project, to devote 3\% of the funds to questions of social concern. This book reveals that he has thought deeply and without judgemental bias on such matters as the importance of public access to DNA sequence data, and the discouraging effects on scientific research and medical applications of overly restrictive patents. The troubling conundrums posed by the present 'intermediate' stage of genetic research, in which we possess "in general the power to diagnose but not to cure" genetic diseases, are illustrated with wrenching real-life situations and put in the context of the analogous history of earlier medical advances. This point is welcome but it could have been acknowledged that too often the routine hype of the academic and corporate biomedical communities, including Watson, has itself made the public impatient for cures.

Curiously, while calling for strict regulation to avoid the dangers of gene therapy, Watson still defends his waffling over the scientific community's actions regarding recombinant-DNA experiments. Although a signatory of the 1974 moratorium letter, he misleadingly describes its contents as calling on scientists worldwide to suspend "all recombinant studies". The letter said no such thing: it asked for a voluntary deferring of only several specific types of recombinant experiment that could "prove biologically hazardous". At the Asilomar Conference in early 1975, six months after the letter was published, Watson joined those who believed that "the moratorium be damned, let's get on with the science". Since then, and again in this book, he has claimed that the scientists' responsible effort yielded "nothing more than five sad years of delay in important research". But the avoidance of restrictive federal legislation in the United States, and this book's description of the rapid scientific progress during the late 1970s, belies his intimidating evaluation.

\section{Although it avoids} Watson's occasional propensity for inflammatory public statements, the book is
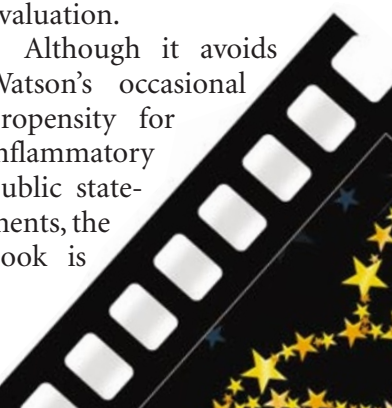
straightforward in decrying the political influence in the United States of fundamentalist religious tenets on the teaching of evolution and the pursuit and application of research on embryos. Watson passionately objects to the current situation, in which US "politicians continue to pander to the outspoken religious minority". And he speaks for many scientists when he says: "I do not dispute the right of individuals to look to religion for a private moral compass, but I do object to the assumption of too many religious people that atheists live in a moral vacuum." These statements would be even more powerful if the chapter on recombinant DNA was not entitled "Playing God", thereby perpetuating a tool used by those who would inhibit modern genetics research.

The unfortunate errors aside, this book is more inclusive and is better reading than similar attempts by science journalists. Although aimed at a general audience, the ignorance among many biomedical scientists of the history of their science suggests that they too can learn a great deal from the book, and enjoy doing so.

Maxine Singer is president emeritus of the Carnegie Institution of Washington, 1530 P Street Northwest, Washington, DC, 20005, USA.

\section{A final call for peace}

The Hedgehog, the Fox, and the
Magister's Pox: Mending the Gap
Between Science and the
Humanities
by Stephen Jay Gould
Harmony: 2003.288 pp. $\$ 25.95$
Published in the UK on 29 May by Jonathan
Cape, E18.99
David Hull

Stephen Jay Gould's Rocks of Ages investigated the relationship between science and religion. In The Hedgehog, the Fox, and the Magister's Pox, published posthumously, Gould turns his attention to the relationship between science and the humanities. During the Renaissance, what we now term 'scientists' were at odds with humanists, whose goal was to recover the wisdom of antiquity, not to generate new ideas by means of empirical investigation. An appropriate mantra for Renaissance humanist scholars was 'been there, done that'. When the sciences cast off the heavy hand of the humanities in the Renaissance, a new adversarial attitude took its place. In this book, Gould strives to outline a more peaceful, mutually supportive view of the relationship between the sciences and the humanities.

Gould sees three ways in which the humanities can contribute to science. First, "science needs the humanities to teach us the quirky and richly subjective side of our own enterprise". The path of science does not run smoothly - at times it is indeed quirky. But is science really subjective, even richly subjective? Gould spends a lot of time debunking the myth of objectivity as a psychological characteristic of scientists. As anyone who studies science soon begins to realize, scientists are not very objective when it comes to their own work, but group objectivity is what matters. Individual scientists may lack objectivity when it comes to their own pet hypotheses, but others will happily take up the slack. Science is organized so that subjectivity can be reduced, resulting in as much objectivity as scientists need.

Gould warns of the great harm done in science and elsewhere by caricaturing one's opponents. The contrast between the traditional 'positivistic' views of science and more recent 'postmodernist' views is ripe for caricature. Supposedly, positivists think that scientists are infallible and provide absolute truth, whereas postmodernists insist that scientists are driven to come up with the views that they do primarily by such social forces as sexism, racism and homophobia. Gould tries to skate between these two extremes. Science is socially embedded, but the recognition of this fact can only aid scientists in their goal of recording and explaining the natural world.

A second contribution that the humanities can make to science is to help scientists improve their communication skills. Gould thinks that academics in general do not write well, with scientists especially deficient in this respect. One of the things that made Gould stand out from his contemporaries was that in general he wrote as well as any humanist ever has. Young academics in departments of English are stuck teaching courses in remedial writing, just as those of us in departments of philosophy are stuck teaching courses in remedial thinking, but neither group is likely to take much satisfaction from the goal that Gould has assigned them.

Finally, Gould claims that those of us in the humanities are charged with setting out the proper boundaries of all magisteria, including science. One of the weaknesses of this book is that Gould does not say enough about his central notion magisteria - and turning to a dictionary does not help. As far as I can tell, magisteria are something akin to areas of expertise shared by groups of experts. About the only characteristic that Gould attributes to magisteria is that they are non-overlapping. Positivists

took it as one of their tasks to define science. Quite a few philosophers of science today think that attempting to draw a line between science and everything else is not very helpful. There is no 'essence' to science, no set of attributes that characterizes all scientists and only scientists throughout all time. Science has evolved and continues to evolve. For some reason, Gould thinks that our concepts must be absolutely sharp to be of any use at all. Despite having a history, Gould argues, they have and must have an essence as well.

A second weakness of this book is that it is largely a collection of essays and parts of essays that have been welded into a single narrative. The seams show. Readers might wonder about the quirky, although arresting, title. The contrast between the hedgehog and the fox is initially meant to distinguish between being very good at one thing (the hedgehog curling up in a ball when attacked) and reasonably good at many things (the fox). He refers to this metaphor frequently in his book, but for me it doesn't add much to his exposition, and the Magister's pox hardly merits a mention except to rhyme with fox. Gould expends much effort arguing that science, once it is properly understood, is not in conflict with the humanities. But he says little about the help, if any, that science can give to the humanities.

Another reason why Gould introduces the notion of magisteria is to help usher in the Age of Aquarius, when peace will guide not only the planets but also academic disciplines. He himself has been badly burned, especially in connection with the controversy over E. O. Wilson's 'sociobiology'. Wouldn't everyone benefit if we all worked together and the lamb were to lie down with the lion? I too like peace and quiet,

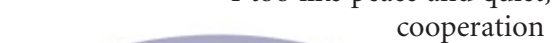

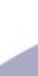

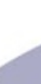

